AGRO EKONOMI, Vol 29, Issue 2, December 2018, Page. 261-273

DOI : http://doi.org/10.22146/ae.36400

ISSN 0215-8787 (print), ISSN 2541-1616 (online)

Available at https://jurnal.ugm.ac.id/jae/

\title{
RELATIONSHIP OF 7P MARKETING MIX AND CONSUMERS' LOYALTY IN TRADITIONAL MARKETS
}

\section{Hubungan Penerapan Bauran Pemasaran 7P dan Loyalitas Konsumen di Pasar Tradisional}

\author{
Hariyani Dwi Anjani ${ }^{1)}$, Irham ${ }^{2)}$, Lestari Rahayu Waluyati ${ }^{3)}$ \\ ${ }^{1)}$ Master Program in Agribusiness Management, Universitas Gadjah Mada \\ ${ }^{2,3)}$ Faculty of Agriculture, Universitas Gadjah Mada \\ St. Flora No.1 Bulaksumur, Sleman, Yogyakarta 55281. Telp. (0274)555675 \\ hariyani.d.anjani@gmail.com
}

Submitted: 23 June 2018; Revised: 5 October 2018; Accepted: 8 November 2018

\begin{abstract}
The existence of traditional market as the center of economic activities in Indonesian society has begun to be displaced by modern market. Improvement in service quality is important in increasing consumers' loyalty in order to retain them. The purposes of this research are: 1) to know the level of 7P's marketing mix in traditional market; 2) to know the level of traditional market consumer's loyalty and 3 ) to determine the relationship between marketing mix implementation with consumer's loyalty. There were 180 traditional market consumers selected by incidental sampling method from 8 traditional markets in Indonesia. Checklists and Likert scale questionnaires were used as tools. Descriptive method was used to analyze data. The result shows that level of marketing mix implementation is high with an average value of $74.07 \%$. The marketing mix elements in order to arrange from the highest to the lowest in level of implementation are respectively those termed People, Process, Physical Evidence, Price, Place, Product, and Promotion. The People element is the highest. This shows that traders' friendliness, alacrity, and honesty are still the hallmarks of traditional markets. The Promotion element is the lowest because most of the merchants do not implement proper promotion. The average of consumers' loyalty level in traditional markets is $77.61 \%$, which is considered high. The 7P's marketing mix, except for the Product aspect, have positive and significant correlation with consumer loyalty, but it is still relatively weak. The consumers would continue to repurchase in traditional markets and recommend that others also shop there.
\end{abstract}

Keywords: consumer, loyalty, marketing mix, traditional market

Anjani, H.D., Irham, \& Waluyati, L.R (2018) Relationship of 7P Marketing Mix and Consumers' Loyalty in Traditional Markets. Agro Ekonomi, 29(2) : 261-273

\section{INTISARI}

Pasar tadisional sebagai pusat kegiatan ekonomi masyarakat Indonesia mulai tergantikan oleh keberadaan pasar modern. Loyalitas konsumen merupakan kunci untuk mempertahankan eksistensi pasar tradisional salah satunya melalui penerapan strategi bauran pemasaran $7 P$. 
Tujuan dari penelitian ini adalah : 1) Mengetahui tingkat penerapan bauran pemasaran $7 P$ di pasar tradisional; 2) Mengetahui tingkat loyalitas konsumen pasar tradisional; dan 3) Mengetahui hubungan bauran pemasaran 7P terhadap loyalitas konsumen. Sampel sejumlah 180 orang konsumen pasar tradisional yang dipilih dengan metode insidental sampling dari 8 pasar tradisional di Indonesia. Pengambilan data dilakukan dengan menggunakan kuesioner berbentuk ceklis dengan skala Likert 1-5. Metode analisis deskriptif digunakan untuk menganalisis data. Hasil menunjukkan bahwa tingkat penerapan bauran pemasaran di pasar tradisional tergolong tinggi dengan nilai rata-rata 74,07\%. Urutan tingkat penerapan aspek bauran pemasaran dari yang tertinggi adalah People, Process, Physical Evidence, Price, Place, Product, dan Promotion. Penerapan aspek People merupakan yang tertinggi. Hal ini menunjukkan keramahan, kesigapan, kejujuran pedagang, masih menjadi ciri utama pasar tradisional. Penerapan promosi merupakan paling rendah. Hal ini karena sebagian besar pedagang tidak melakukan promosi secara masiv. Rerata tingkat loyalitas konsumen pasar tradisional 77,61\% tergolong tinggi. Penerapan bauran pemasaran 7P, kecuali aspek Product, berkorelasi positif terhadap loyalitas konsumen, namun hubungannya masih tergolong lemah. Konsumen akan berbelanja kembali ke pasar tradisional dan merekomendasikan oranglain berbelanja di sana.

Kata kunci : bauran pemasaran, konsumen, loyalitas, pasar tradisional.

\section{INTRODUCTION}

The traditional market has a strategic role in Indonesia. It is a source of livelihood for more than 13 million traders and 9 million street vendors. The traditional market is the main place for selling such products as those of agriculture, fishery, handicraft, and home industry. The traditional market provides daily necessities like vegetables, fruits, meat, fish, eggs, clothing, household appliances, and so on (Pramono et al., 2011).

However, the existence of the traditional market as most people's economic center in Indonesian society has begun to be displaced by the modern market. Nielsen (2015) presented study results indicating that modern markets in Indonesia including convenience stores, minimarkets, supermarkets, and hypermarkets, grows as much as $31.4 \%$ per year while traditional markets decrease as much as $8 \%$ per year. It has occurred not only in Indonesia but also in Asia generally. Nielsen (2015) recorded that traditional markets in 1999 has dominated Asia's trade of $73 \%$. And then, in 2012, the domination fell to $56 \%$, with the condition where they were being displaced by modern markets. It is predicted that in 2020 the contribution of modern markets in Asia would be more dominant, being as much as $57 \%$, while traditional markets would contribute as much as only $43 \%$. Suryadarma et al. (2010) stated that the existence of modern markets had experienced the decrease of income within traditional traders. In the 2003-2006, the average income of 
traditional market traders decreased by $26.48 \%$. Their average profit also decreased by $30.47 \%$ since buyers shifted to the modern market.

The traditional market has been known to have a hot atmosphere, a dirty environment, bad odors, narrow and cramped spaces, disorganized goods, muddy passageways, and weak security systems, presenting a negative impression to the consumers. However, traditional markets still have some advantages such as providing shopping places closer to home, lower and negotiable prices, products that are more diverse and fresh, good interactions with traders, and easy purchase through credit payments which are available for customers (World Bank and the Trade Department of the Republic of Indonesia, 2007). The marketing mix (which could be regarded as the set of marketing tools) should be well managed to attract consumers to repurchase the products in traditional markets.

Kotler and Keller (2009) define the marketing mix as a combination of market activities for certain goods or services over a given period and in a particular market. According to Agic et al., (2016), marketing strategy is related to the creation of a marketing mix which enables a business to achieve its objectives in the targeted market. As consumers' behavior changes, the marketing mix is not only concerned with $4 \mathrm{P}$ but also developed into 7P (Harrington et al., 2017) which are mentioned as follows:

1. Product is a marketing effort related to everything offered to meet consumer needs (Kotler and Keller, 2009). Product mix consists of product type, quality, design, completeness, brand name, packaging, size, product service, warranty and replacement (Kukanja et al., 2016).

2. Price is the marketing mix element of how much money consumers spend to buy the product to fulfil their needs and desires. Tjiptono and Chandra (2005) mentioned that at a certain price level, if the perceived benefits of consumers increases, then its value will increase as well (Kotler and Keller, 2009).

3. Place is the market location or area where the merchant sell or distribute his wares so that it is available to the consumer. Kushwaha and Agrawal (2015) explained that decision for physical distribution decisions considers on how the order is processed, on where the storage is located, how much the preparation has to be ready, and how the goods should be transported.

4. Promotion is an effort to convey information or to communicate between traders and consumers with the aim of disseminating information, influencing, persuading, and reminding target markets in order to create demand for 
products or services offered by traders

(Marques et al., 2014)

5. People element could be defined as the role of humans in the delivery of goods or services that can affect consumer perceptions (Kukanja et al., 2016). According to Kushwaha and Agrawal (2015), the customer-oriented employees focus on showing personal attention, interpersonal care, politeness and fast behavior.

6. The process describes the method and sequence in the service and creates a promised value to the customer by serving the demand of each customer (Kushwaha and Agrawal, 2015). The element of process includes the facilities in buying and selling, and the quick response of sellers to meet the demand of consumers, the agile response to consumers complaints for products and services (Yarimoglu, 2014).

7. Physical Evidence focuses on the physical conditions in the place of business including the surrounding area. (Khan, 2014). Physical evidence of marketing elements include the supporting environment (furniture, color, layout, noise level), supporting goods, spatial, hygiene and equipment, supporting facilities such as toilets, mosque and parking lots (Kukanja et al., 2016).

Successful marketers are those who maintain not only their company profits but also their consumers and consumers' loyalty (Lamberti and Noci, 2010). Loyalty is defined as a deeply held commitment to buy or to support a preferred product or service in the future even if the influence of the marketing situation and effort has the potential of causing consumers to shift their preference (Kotler and Keller, 2009). Merrilees et al., (2011) stated that consumers' confidence is a substantial variable in marketing decisions. Picón-Berjoyo et al., (2016) stated that loyalty is a major determinant of corporate performance. Consumers' loyalty is closely related to customers' satisfaction (Kasiri et al., 2017). When consumers are satisfied, they would not only repurchase products of the company, but also recommend the good things about the company and its products to others (Orel \& Kara, 2014).

Consumers are the key to the existence of traditional markets. Improving services is important as an effort to increase consumers' loyalty in order to retain them. It could be done by optimizing the management of marketing-mix elements (Tjiptono and Chandra, 2005). In relation to it, the primary aims of this research are to determine the implementation level of the marketing mix elements called Product, Price, Place, Promotion, People, Process, and Physical Evidence and to identify the level of consumers' loyalty and to determine the relationship between marketing mix implementation with consumer's loyalty in the traditional market. 


\section{METHODS}

Primary and secondary data were collected to support the research. The primary data were collected by interviewing consumers of the traditional market (who were people who had been shopping in the traditional market at the time of research) in eight traditional markets located in six districts in Indonesia. They were the Kemukiman Saree Market in Aceh Besar; the Kelapa Kampit and Sukamandi Markets in East Belitung; the Andolou Utama (DU) Market in South Konawe; the Caplek and Waringin Markets in Cilacap, the Sedo Market in Demak, and the Bululawang Market in Malang. The locations were chosen because they were the place for the optimization of rural area market development programs in 2017 by the Ministry of Village, Development of Disadvantaged Regions and Transmigration of the Republic of Indonesia. The research was conducted in June 2017. There were 180 respondents serving as the research sample chosen by using the incidental sampling method. Likert-scale questionnaries were used as the instruments in the study, measuring by using a 1-5 scale. There were three stages used in the effort to know the level of the 7P marketing mix implementation and consumers' loyalty in the traditional market:

1) Calculating the scores of each scale and then calculating the total score,
Score for Extremely $=\sum$ EA $\times 5=A$ Agree (EA)

Score for Agree (A) $=\sum A \quad \mathrm{x} 4=\mathrm{B}$

Score for Neutral $=\sum N \quad$ x $3=C$

(N)

Score for Disagree $=\sum D \quad$ x $2=D$

(D)

Score for Extremely $=\sum E D \times 1=E$ Disagree (ED)

Total Score $=\mathrm{X}$

2) Calculating the marketing mix implementation and consumers' loyalty level by dividing the total score (X) with the maximum score (Y). Y was obtained from the multiplication of the total sample (n) with the highest Likert scale (ie 5). Maximum score $=\sum$ samples x $5=$ Y. Level of marketing mix and consumers loyalty $=\frac{X}{Y} \times 100 \%$

3) Matching the value resulted from the level of marketing mix implementation and consumers' loyalty with the criteria that used. It can be seen in Table 1 .

Table 1. Criteria of Marketing Mix Implementation and Consumers' Loyalty Level

\begin{tabular}{ll}
\hline Level $(\%)$ & Category \\
\hline $20,00 \leq \mathrm{n} \leq 35,99$ & Very Low \\
$36,00 \leq \mathrm{n} \leq 51,99$ & Low \\
$52,00 \leq \mathrm{n} \leq 67,99$ & Medium \\
$68,00 \leq \mathrm{n} \leq 83,99$ & High \\
$84,00 \leq \mathrm{n} \leq 100,00$ & Very High \\
\hline
\end{tabular}

Source : Terho \& Jalkala (2017)

\section{RESULTS AND DISCUSSION}

There were eight traditional markets from six districts scattered in five provinces in Indonesia chosen as the 
research locations. Each market has its own characteristics in terms of location, market area, building specifications, operational time, and product types sold. In running the business, traders need to make efforts in order to attract buyers to buy products. The efforts are often called as the marketing mix. Traders in traditional markets are often unaware that what they do is part of the marketing mix. In the study concerned here, the 7P marketing mix consists of Product, Price, Place, Promotion, People, Process, and Physical Evidence as its elements. Based on observations, 70\% of traditional market consumers were woman. Most of them are housewives. Consumer age varies between 15-64 years. Educational background is quite evenly distributed from elementary school to college. Most consumers were categorized as the lower middle class, their earning less than 3 million rupiah. The distance of consumers house to the market is around $0-5 \mathrm{~km}$. Usually they use motorbikes to go to the market.

Products sold in traditional markets were quite diverse, covering food products/ groceries, vegetables, fruits, fish, meat, various processed foods, household appliances, clothing, and others. Each type of product has different quality standards so that product quality was not included in the Product element. However, there are some markets that are considered incomplete. The Sukamandi Market is an example of such a market because of its small place and few number of traders. Another market concidered incomplate is the Saree Market, dominantly selling fruit and processed chips as souvenirs. Packaging is required to enable consumers carry their groceries and protect goods from being damaged and dirty (Selang, 2013). The packaging used by merchant in the markets is in the form of plastic bags. It is considered practical and sufficiently adequate.

In general, the average level of the Price element implementation was high. One characteristic of the traditional market is the price of the product which is negotiable while in the modern market the price is determined to be fixed. Consumers in traditional markets are accustomed to bargaining prices in the hope of getting a price lower than that offered (Singh, 2015). The products that are usually with negotiable prices are clothes, bags, shoes, fruit, meat, and vegetables. However, there are some merchants that sell products at fixed prices. As the second indicator of the Price element, traders have followed developments of the prices in the market and they inform consumers transparently. Furthermore, discounts are usually given to customers for purchasing products belonging to certain types of goods in large quantities.

The Place aspect is related to location and product availability. The average level of Place was high. The highest indicator is the strategic market location. It shows 
that traditional markets are generally close to consumers, and quite accessible. The distance from consumers home to the market is mostly less than $5 \mathrm{~km}$. Markets are located nearby the main roads. Some merchants provide services in delivering orders to the consumer premises. Identity of location is important to show where the traditional market is located. All markets have it. However, the merchant mostly do not use banners or nameplate. The existence of location identity makes consumers be easier to find the market. The products that are continvesly available make it easier for consumers to buy the goods they want. Merchants need to organize the availability of the goods by checking the stock periodically and arranging the procurement. In 7P's marketing mix, convenience indicators for shopping included in physical evidence element.

Promotion in the traditional market is applied in a simple way. Based on the investigation, it is known that the implementation of bonuses for the purchase of a certain quantity is within medium level. Bonus providd by the merchant is usually formed as additional weight

Table 2. Level of 7P Marketing Mix Implementation in Traditional Market

\begin{tabular}{|c|c|c|c|c|}
\hline Elements & Indicators & Level $(\%)$ & Average $(\%)$ & Category \\
\hline \multirow{3}{*}{ Product } & Product diversity & 71.44 & \multirow{3}{*}{71.22} & \multirow{3}{*}{ High } \\
\hline & Adequate packaging & 69.56 & & \\
\hline & Well-done packaging & 72.67 & & \\
\hline \multirow{4}{*}{ Price } & Cheaper Price & 66.22 & \multirow{4}{*}{72.25} & \multirow{4}{*}{ High } \\
\hline & Follow price development & 73.78 & & \\
\hline & Negotiable Price & 75.44 & & \\
\hline & Offering Discount & 73.56 & & \\
\hline \multirow{3}{*}{ Place } & Strategic location & 81.44 & \multirow{4}{*}{71.81} & \multirow{4}{*}{ High } \\
\hline & Delivery service & 68.78 & & \\
\hline & Place identity & 69.33 & & \\
\hline \multirow{5}{*}{ Promotion } & Product availability & 67.67 & & \\
\hline & Simple Bonus of Purchasing & 69.89 & \multirow{3}{*}{66.37} & \multirow{3}{*}{ Medium } \\
\hline & Mouth-of-Word Promotion & 65.33 & & \\
\hline & Media Information (HP/Leaflet) & 63.89 & & \\
\hline & Manage business by itself & 78.89 & \multirow{4}{*}{81.22} & \multirow{4}{*}{ High } \\
\hline \multirow{3}{*}{ People } & Hospitable attitude & 84.00 & & \\
\hline & Alacrity/Agile/ Quick Response & 81.44 & & \\
\hline & Honesty & 80.56 & & \\
\hline \multirow{2}{*}{ Process } & Bargaining in kindship & 81.11 & \multirow{2}{*}{79.00} & \multirow{2}{*}{ High } \\
\hline & Payment fleksibility & 76.89 & & \\
\hline \multirow{3}{*}{$\begin{array}{l}\text { Physical } \\
\text { Evidence }\end{array}$} & Market cleankliness & 72.89 & \multirow{3}{*}{76.63} & \multirow{3}{*}{ High } \\
\hline & Neatly arranged & 77.44 & & \\
\hline & Shopping Flexibility/Convenience & 79.56 & & \\
\hline Average & & & 74.07 & High \\
\hline
\end{tabular}

Source : Primary Data Analysis (2018) 
and products upon certain purchases. In addition, there is also bonus in the form of giving a certain item for free to the loyal consumers. But not all merchants apply it. The implementation of the word-ofmouth promotion is medium in level. Some merchants offer their merchandise to pass consumers; others just wait for consumers to come. Furthermore, the implementation of promotion through several media such as mobile phones, leaflets, and even social media is at the lowest level. Merchants have shifted from making leaflets to employing the more widely used mobile phones (Brooks and Simkin, 2012). But their use of the mobile phone is still limited to informing and receiving orders from consumers. There are traditional market traders who use the Internet to offer their products and clothing. Rahmaningtyas et al., (2017) explains that online sales make it easier for consumers to buy products. The average level of Promotion implementation is medium.

The implementation level of the People element in traditional markets is high. One of the dominant traits of traditional markets is the friendly attitude of merchants towards consumers. The merchant greets the consumer, presents the product with a smile, and is responsive to the information of what the customer is looking for. The chatting and joking going on between the merchant and the buyer result in intimacy and comfortable feelings. The friendly attitude of the merchant is important for the consumer (Singh, 2015). Alacrity is shown by the merchant serving quickly and being responsive when the consumer makes an order. Merchants in traditional markets are mostly honest. It is reflected in the right weighing and the correct delivery of information in the case when the goods available are not good in quality so that consumers are not disappointed. Most traditional merchants manage their own businesses. There are some merchants who are assisted by employees. The merchant who manages his own business is usually more knowledgeable about the types of the products, the selling prices, and other information about the products sold so that such a merchant could serve customers more quickly.

The average level of Process elements is high. The existence of a bargain is one of the characteristics of traditional markets. A bargaining process conducted in a familial manner can lead into intimacy and convenience for the consumer (Suryadarma et al., 2010). Implementation level of this indicator is high. Payment flexibility is high, meaning that consumer can pay in credit way. This usually happens to consumers who are already customers to a particular merchant, have a close relationship with the merchant, and purchase in large quantities.

The marketing mix indicators related to Physical Evidence include location hygiene, tidiness in product arrangement, and customer's flexibility or convenience 
in shopping (Lee, 2017). Hopefully, if the traditional market is clean, it is neatly arranged, and the layout makes consumers freely shop, it would provide consumers with satisfaction and increase their loyalty (Rathee dan Kumar, 2013). The average level of Physical Evidence implementation is high. There is the presence of cleaners who sweep the market area and of the garbage disposal bins provided to keep the market clean. The neat product arrangement is high in implementation level. It means that most merchants manage their products neatly. Tidiness in product layout is indicated in the neat arrangement of products which, being grouped by type, are beautiful to look at and facilitate consumers in easily finding the product they want to buy. Consumers' shopping flexibility is high in level of implementation. It shows that consumers feel comfortable, safe, and free to choose the desired product because of the passageways between kiosks or stalls are spacious enough to make it easier for consumers to shop in the traditional market. So, it provide convenience for consumers.

Over all, 7P marketing mix implementation level in traditional markets is high. People elements was the highest and Promotion level was the lowest. The average implementation level of the Process element is high. The existence of bargaining is one of the characteristics of traditional markets. A bargaining process conducted in a familial manner could lead to intimacy and convenience for the consumer (Suryadarma et al., 2010). The implementation level of this indicator is high. Payment flexibility is high in level of implementation, meaning that the consumer could pay the goods on credit. It usually happens to consumers who are already customers to particular merchants, have a close relationship with the merchant, and purchase in large quantities from the merchant.

Consumers' loyalty is an in-depth customers' commitment to buying or re-favoring a preferred product in the future as shown by repurchasing it and recommending that others shop at traditional markets (Srivastava and Kaul, 2016). Traditional markets generally provide basic human needs such as food and clothing. Consumers who are loyal would return to the traditional market in order to meet their needs. Another reason is that the traditional market in the research area is located close to the consumer's home. According to Table 3, it is known that consumers want to be back shopping at traditional markets but are less willing to recommend that others shop in traditional

Table 3. Level of Consumers Loyalty in Traditional Market

\begin{tabular}{lcc}
\hline Loyalty Indicators & $\begin{array}{c}\text { Loyalty } \\
\text { Level (\%) }\end{array}$ & Category \\
\hline Repurchase & 83.22 & High \\
Recommand Others & 72.00 & High \\
Average & 77.61 & High \\
\hline
\end{tabular}

Source : Primary Data Analysis (2018) 
Table 4. Correlation of 7P's Marketing Mix toward Consumers Loyalty

\begin{tabular}{lccccccc}
\hline & Product & Price & Place & Promotion & People & Process & Physic \\
\hline Loyalty & 0.101 & $0.244^{* *}$ & $0.225^{* *}$ & $0.158^{*}$ & $0.234^{* *}$ & $0.192^{* *}$ & $0.309^{* *}$ \\
\hline ** Correlation is significant at the 0.01 level (2-tailed) & & & \\
* Correlation is significant at the 0.05 level (2-tailed) & & &
\end{tabular}

markets. This is indicated by the value of the loyalty level in the first indicator being much higher than that in the second one. Traditional markets in rural areas are the main places for the people to do their shopping. Hence, they would be back shopping at traditional markets.

Correlation analysis is a method of statistical evaluation used to study the strength of a relationship between two variables and the direction of the association. In this research, Pearson Product Moment correlation coefficient (r) was estimated. The value of $r$ ranges between +1 and -1 . Based on reseach result in Table 4, it is known that all of 7P's marketing mix variable are positively and significantly correlated with consumers loyalty, except Product variable. Correlation value of Price, Place, People, and Physical Evidence are low, while Promotion and Process are very low. This shows that there is a weak relationship between the marketing mix and consumers loyalty. While the direction of the relationship is positive, so the higher the marketing mix implementation, the higher the consumer loyalty is. Consumers' loyalty of traditional market can be increased by improving the marketing mix implementation specifically
Physical Evidence, Price, People, Place, Process, and Promotion aspects.

\section{CONCLUSION AND SUGGESTION}

The implementation of the marketing mix in traditional markets according to consumers is considered as high $(74.07 \%$.) The highest level of the marketing mix implementation is the People element. According to the indicator of merchants serving consumers with friendliness, the lowest level is the implementation of the Promotion element and especially according to the indicator of dissemination of promotional information through various media (especially by mobile phone or leaflet). The implementation level from the highest to the lowest in order is the marketing mix elements are People, Process, Physical Evidence, Price, Place, Product, and Promotion. Traditional market consumers are loyal proven with the loyalty level of $77.61 \%$, which is considered high in the category. They are willing to repurchase in traditional markets and recommend that others also shop there. 7P's marketing mix variable are positively and significantly correlated with consumers loyalty, except Product variable. Taditional market loyalty can be improved by increasing marketing 
mix implementation especially Physical Evidence, Price, People, Place, Process, and Promotion aspects.

Merchants are advised to improve the lower-level implementation of the marketing mix especially in relation with the Place and Promotion elements in some ways such as increasing delivery services, giving store identities, maintaining product availability, and increasing promotions by giving bonuses, applying word-of-mouth promotion, and using mobile phones as promotional media. Merchants are advised to keep market cleanliness and shopping convenience. In addition, it should provide cheaper and negotiable price, keep merchant's hospitality, alacrity and honesty. There is a need for cooperation among various stakeholders to continue increasing consumers' loyalty to traditional markets. Further research could be directed to determine the variables affecting consumers' loyalty in traditional markets.

\section{REFERENCES}

Agic, E., Cinjarevic, M., Kurtovic, E., \& Cicic, M. (2016). Strategic marketing patterns and performance implications. European Journal of Marketing, 50(12), 2216-2248. https://doi. org/10.1108/EJM-08-2015-0589

Brooks, N., \& Simkin, L. (2012). Judging marketing mix effectiveness. Marketing Intelligence \& Planning,
$30(5), 494-514$. https://doi. org/10.1108/02634501211251025

Harrington, R. J., Ottenbacher, M. C., \& Fauser, S. (2017). QSR brand value. International Journal of Contemporary Hospitality Management, 29(1), 551570. https://doi.org/10.1108/ IJCHM-06-2015-0300

Kasiri, L. A., Guan Cheng, K. T., Sambasivan, M., \& Sidin, S. M. (2017). Integration of standardization and customization: Impact on service quality, customer satisfaction, and loyalty. Journal of Retailing and Consumer Services, 35(June 2016), 91-97.

Khan,M.(2014). The Concept of Marketing Mix and its Elements (A Conceptual Review) International Journal of Information, Business and Management, 6(2), 95-107.

Kotler, P., \& Keller, K. L. (2009). Manajemen Pemasaran. Jakarta: Penerbit Erlangga.

Kukanja, M., Omerzel, D. ., \& Kodrič, B. (2016). Ensuring restaurant quality and guests' loyalty: an integrative model based on marketing (7P) approach,. Total Quality Management \& Business Excellence, 1-17. 
Kushwaha, G. S., \& Agrawal, S. R. (2015).

An Indian customer surrounding

7Ps of service marketing. Journal of Retailing and Consumer Services, 22, 85-95. https://doi.org/10.1016/j. jretconser.2014.10.006

Lamberti, L., \& Noci, G. (2010). Marketing strategy and marketing performance measurement system : Exploring the relationship. European Management Journal, 28(2), 139-152. https://doi. org/10.1016/ j.emj.2009.04.007

Lee, S. (2017). Study on Traditional Market Decline and Revitalization in Korea: Improving the Iksan Jungang Traditional Market. Journal of Asian Architecture and Building Enginering, 455-462.

Marques, A., Lacerda, D. P., Camargo, L. F. R., \& Teixeira, R. (2014). Exploring the relationship between marketing and operations: Neural network analysis of marketing decision impacts on delivery performance. International Journal of Production Economics, 153, 178-190. https:// doi.org/10.1016/ j.ijpe.2014.02.020

Merrilees, B., Rundle-thiele, S., \& Lye, A. (2011). Industrial Marketing Management Marketing capabilities : Antecedents and implications for B2B SME performance. Industrial
Marketing Management, 40(3), 368-375.

Nielsen (2015). Maximising Traditions : The Shop. Shopper. Shopkeeper. The Nielsen Company, (October).

Orel, F. D., \& Kara, A. (2014). Supermarket self-checkout service quality, customer satisfaction, and loyalty: Empirical evidence from an emerging market. Journal of Retailing and Consumer Services, 21(2), 118-129.

Picón-Berjoyo, A., Ruiz-Moreno, C., \& Castro, I. (2016). A mediating and multigroup analysis of customer loyalty. European Management Journal, 34(6), 701-713. https://doi. org/10.1016/j.emj.2016.07.006

Pramono, A., Santoso, A., \& Indriyono, P. (2011). Menahan Serbuan Pasar Modern : Strategi Perlindungan dan Pengembangan Pasar Tradisional. Lembaga Ombudsman Swasta DIY.

Rahmaningtyas, A., Hartono, S., \& Suryantini, A. (2017). Factors Affecting Online Purchasing of Local Food. Agro Ekonomi, 28(2), 189-204.

Rathee, S., \& Kumar, J. (2013). Rural Marketing Environment : A Conceptual Framework. Asia Pasific Journal of Marketing \& Management Review, 2(9), 64-74. 
Selang, C. A. D. (2013). Bauran Pemasaran.

Pengaruhnya terhadap Loyalitas

Konsumen pasa Fresh Mart Buhu

Mall Manado. Jurnal EMBA 71, 1(3), 71-80.

Singh, P. (2015). Marketing Mix Strategies for FMCG in Rural India A Competitive Player in FMCG. Global Journal of Enterprise Information System, 2-6.

Srivastava, M., \& Kaul, D. (2016). Exploring the link between customer experience-loyalty-consumer spend. Journal of Retailing and Consumer Services, 31, 277-286. https://doi. org/10.1016/j.jretconser.2016.04.009

Suryadarma, D., Poesoro, A., Budiyati, S., Rosfadhila, M., \& Suryahadi, A. (2010). Traditional food traders in developing countries and competition from supermarkets : Evidence from Indonesia. Food Policy, 35(1), 79-86. https://doi.org/10.1016/j. foodpol.2009.11.002
Terho, H., \& Jalkala, A. (2017). Customer reference marketing: Conceptualization, measurement and link to selling performance. Industrial Marketing Management, 64,175-186. https://doi.org/10.1016/ j.indmarman.2017.01.005

Tjiptono, F., \& Chandra, G. (2005). Service, Quality, and Satisfaction. Yogyakarta: Penerbit Andi.

World Bank, \& Trade Department of Republic Indonesia. (2007). Survey of Consumers Shopping Behavior and Perceptions toward Modern and Traditional Trade Channels. Jakarta: Trade Departmen of Republik Indonesia.

Yarimoglu, E. K. (2014). A review on dimensions of service quality models. Journal of Marketing Management, 2(2), 73-93. 